IJMS 17 (1), 149-170 (2010)

\title{
HALAJU WANG DI MALAYSIA: BUKTI EMPIRIK
}

\author{
ZULKEFLY ABDUL KARIM \\ MANSOR JUSOH \\ NORLIN KHALID \\ Fakulti Ekonomi dan Perniagaan \\ Universiti Kebangsaan Malaysia
}

\begin{abstract}
ABSTRAK
Kajian ini bertujuan untuk menguji kemeruapan (volatility) halaju wang di samping menganggar fungsi halaju wang di Malaysia dengan menggunakan kaedah ekonometrik siri masa iaitu model ARCH dan GARCH, ujian kointegrasi Johansen dan ujian model vektor pembetulan ralat (VECM). Dapatan kajian menunjukkan bahawa halaju wang M1 (V1) dan halaju wang M2 (V2) mempunyai kemeruapan yang berkelangsungan (persistence) berbanding dengan kemeruapan halaju wang M3 (V3). Keputusan ujian kointegrasi Johansen pula menunjukkan kewujudan hubungan jangka panjang antara halaju wang V1, V2 dan V3 dengan pemboleh ubah bebas yang terdiri daripada kadar bunga bon, kadar bunga deposit dan pendapatan negara. Selain itu, ujian VECM menunjukkan bahawa perubahan pemboleh ubah bebas iaitu kadar bunga bon, kadar bunga deposit dan pendapatan negara signifikan menjadi penyebab kepada perubahan halaju wang V2 dan V3 dalam jangka panjang. Sebaliknya, dalam jangka pendek didapati perubahan pendapatan negara hanya signifikan menjadi penyebab kepada perubahan halaju wang V2 dan V3 sahaja. Pengaruh kadar bunga hanya signifikan menjadi penyebab jangka pendek kepada halaju wang V3 sahaja. Kajian ini memberikan beberapa implikasi penting kepada dasar kewangan negara.
\end{abstract}

Kata kunci: Halaju wang; kemeruapan; ekonometrik siri masa.

\begin{abstract}
Purpose - This paper aims to examine the volatility of money velocity and also estimate the velocity of money function in Malaysia by using quarterly time series data.

Design/Methodology/Approach - This study employed recent econometric techniques such as volatility model in ARCH and GARCH frameworks, Johansen co integration test, and Vector Error Correction Model (VECM).
\end{abstract}


Findings - The results showed that the velocity of money for M1 (V1) and M2 (V2) are volatile and persistence rather than M3 (V3). The Johansen co-integration test result indicated that the existence of long-run relationships between velocity of money V1,V2 and V3 on the dependent variables, such as bond interest rate, deposit rate, and income. Furthermore, the VECM result showed that the changes in dependent variables such as bond interest rate, deposit rate, and income do significantly influence the changes in velocity of money for V2 and V3 in the long run. Conversely, in the short run, a change in the national income has only significantly caused changes in the velocity of money V2 and V3, while the interest rate is significant in causing the velocity of money $V 3$.

Originality/Value - This paper explores extensively the modern econometric techniques in investigating the issue of volatility and velocity of money in Malaysia.

Keywords - Velocity of money; volatility; time series techniques.

Paper type - Research paper.

\section{Pengenalan}

Teori kuantiti wang mengandaikan halaju wang adalah stabil kerana beranggapan tidak berlakunya perubahan institusi dan inovasi kewangan di sesebuah negara walaupun dalam jangka panjang. Maka, dalam hal ini perlaksanaan dasar kewangan melalui pengembangan penawaran wang tidak akan mengubah pendapatan benar, sebaliknya akan meningkatkan paras harga umum yang berkadaran dengan perubahan penawaran wang nominal. Walau bagaimanapun, andaian ini adalah tidak berasas kerana pemodenan dan inovasi dalam sistem kewangan serta perubahan institusi di sesebuah negara akan menyebabkan fungsi halaju wang berubah-ubah dan tidak stabil. Sebagai contohnya, Bordo dan Jonung (1981;1987) menekankan bahawa perubahan teknologi dalam sistem pembayaran, penambahbaikan dalam sistem komunikasi dan pembangunan dalam sistem perbankan secara menyeluruh merupakan faktor utama yang menyumbang kepada perubahan halaju wang.

Halaju wang memainkan peranan penting dalam kegiatan ekonomi di sesebuah negara. Secara amnya, halaju wang mengukur nisbah antara pendapatan nominal dengan stok wang. Halaju wang akan berkurangan jika stok wang meningkat dengan kadar yang lebih cepat berbanding dengan peningkatan pendapatan nominal dan sebaliknya. Sebagai contohnya, negara yang mengalami peningkatan dalam kadar pertumbuhan pendapatan benar cenderung mengalami peningkatan dalam kadar stok wang yang mana kemudiannya akan mengurangkan halaju wang. Semakin 
tinggi halaju wang dalam ekonomi, maka semakin cepatlah pertumbuhan ekonomi. Walau bagaimanapun, peningkatan mendadak halaju wang juga boleh mencetuskan masalah inflasi dalam negara. Justeru, pihak berkuasa kewangan perlulah memantau halaju wang dari masa ke semasa supaya selari dengan matlamat ekonomi yang diingini misalnya kestabilan paras harga umum. Ini kerana, halaju wang yang stabil akan memudahkan pihak berkuasa kewangan untuk membuat pilihan strategi dasar kewangan yang bersesuaian khususnya mengawal agregat kewangan. Sebaliknya, ketidakstabilan dalam fungsi halaju wang sudah pasti menyukarkan perlaksanaan dasar kewangan negara untuk membuat kawalan terhadap aggregat kewangan.

Isu kestabilan dan kemeruapan halaju wang juga mempunyai kaitan yang rapat dengan kestabilan fungsi permintaan wang. Peningkatan permintaan wang akanmenyebabkankejatuhanhalaju wang dansebaliknya pengurangan permintaan wang akan menyebabkan peningkatan halaju wang. Sebagai contohnya, pengurangan permintaan wang cenderung menyebabkan orang ramai meningkatkan perbelanjaan penggunaan yang mana menyebabkan semakin kerap wang beredar dalam pasaran dan sekaligus meningkatkan halaju wang. Atas alasan inilah fungsi halaju wang di sesebuah negara berkecenderungan berubah dan mengalami ketidakstabilan setiap masa. Maka, hubungan antara permintaan wang dengan halaju wang perlulah dikaji bagi mengenal pasti faktor-faktor utama yang mempengaruhi halaju wang untuk kepentingan perlaksanaan dasar kewangan negara.

Justeru, objektif utama kajian ini ialah untuk menguji kemeruapan halaju wang di samping menganggar fungsi halaju wang di Malaysia dengan menggunakan kaedah ekonometrik siri masa yang terkini iaitu model ARCH, GARCH, ujian kointegrasi Johansen (1988) dan model vektor pembetulan ralat. Bagi memudahkan perbincangan, kajian ini dibahagikan kepada beberapa bahagian. Bahagian kedua membicarakan latar belakang teori halaju wang dan kajian lepas. Bahagian ketiga pula membincangkan metodologi kajian, manakala bahagian keempat membentangkan keputusan kajian. Akhir sekali, bahagian kelima merumus dan membincangkan implikasi kepada dasar kewangan negara.

\section{Teori Halaju Wang dan Kajian Lepas}

\section{Teori Halaju Wang}

Halaju wang bermaksud berapa kali setiap ringgit berpusing ganti untuk membeli barangan dan perkhidmatan akhir. Halaju wang boleh diterbitkan daripada persamaan pertukaran yang dikemukakan oleh Fisher (1930).

IJMS 17 (1), 149-170 (2010) 
Secara ringkas, persamaan pertukaran dapat dijelaskan seperti berikut;

$M V=P Y$

yang mana $M V$ mengukur perbelanjaan terhadap barangan dan perkhidmatan akhir dalam suatu tempoh, manakala $P Y$ ialah nilai nominal output. Daripada persamaan (1), jelas menunjukkan jumlah perbelanjaan terhadap barangan dan perkhidmatan akhir adalah sama dengan nilai Keluaran Dalam Negara Kasar (KDNK) nominal atau juga bermaksud indeks halaju penawaran wang adalah menyamai nilai KDNK nominal.

Daripada persamaan (1), untuk menganggarkan halaju wang $\left(V^{e}\right)$, kita perlu membahagikan pendapatan nominal dengan kuantiti nominal baki wang yang ingin dipegang oleh orang ramai. Katakan, $M^{d}$ merupakan baki kuantiti wang benar yang ingin dipegang oleh orang ramai. Maka, $P M^{d}$ ialah permintaan yang nominal. Justeru, untuk menganggar $V^{e}$, perlulah dibahagikan $P Y$ dengan $P M^{d}$. Keputusan ini menjelaskan halaju wang yang dirancang adalah sama dengan nisbah antara pendapatan benar dengan permintaan wang benar, seperti yang ditunjukkan dalam persamaan (2) atau persamaan (3).

$$
V^{e}=\frac{P Y}{P M^{d}}
$$

atau

$$
V^{e}=\frac{Y}{M^{d}}
$$

Persamaan (3) mewakili halaju edaran wang yang merupakan teori permintaan wang. Oleh kerana permintaan wang merupakan pemboleh ubah pembawah (denominator), maka pengurangan dalam permintaan wang akan diikuti dengan peningkatan halaju wang, dan sebaliknya peningkatan permintaan wang pula akan menyebabkan pengurangan halaju wang. - Maka, untuk menentukan faktor-faktor yang mempengaruhi halaju wang, kita perlulah mengenal pasti faktor-faktor yang mempengaruhi permintaan wang. Justeru, persamaan (3) boleh diubah seperti berikut;

$$
V^{e}=\frac{Y}{M^{d}\left(I-R_{d}, Y\right)}=V^{e}\left(I-R_{d}, Y\right)=V^{e}\left(I, R_{d}, Y\right)
$$

Daripada persamaan (4), kadar bunga bon kerajaan (I) berhubungan positif dengan $V^{e}$, manakala kadar bunga deposit $\left(R_{d}\right)$ pula berhubungan negatif dengan $V^{e}$. Sebaliknya, kesan peningkatan pendapatan $(Y)$ terhadap halaju 
wang adalah tidak dapat ditentukan hubungan tersebut (iaitu mungkin positif, negatif atau tiada kesan terhadap $V^{e}$ ) kerana sebarang peningkatan $Y$ akan memberikan kesan kepada kedua-dua pemboleh ubah pengatas (numerator) dan pembawah (denominator). Kesan pendapatan terhadap halaju amat bergantung kepada setakat mana responsifnya permintaan wang terhadap perubahan pendapatan. Ini dapat ditunjukkan oleh keanjalan pendapatan terhadap permintaan wang iaitu, diukur melalui peratusan perubahan permintaan wang dibahagikan dengan peratusan perubahan pendapatan benar.

Maka, berdasarkan kepada persamaan (4), kita boleh membentuk fungsi linear halaju yang seperti berikut;

$$
V^{e}=v_{0}-v_{1} R_{d}+v_{2} I \pm v_{3} Y
$$

yang mana $V^{e}$ ialah anggaran halaju wang yang terdiri daripada halaju wang M1 atau V1, halaju wang M2 atau V2 dan halaju wang M3 atau V3, $v_{0}$ ialah intersep (konstan), $v_{1}, v_{2}$ dan $v_{3}$ ialah koefisien, $R_{d}$ ialah kadar bunga deposit, $I$ ialah kadar bunga bon kerajaan dan $Y$ ialah Keluaran Dalam Negara Kasar.

\section{Kajian Lepas Halaju Wang}

Kebanyakan kajian mengenai isu halaju wang di negara maju lebih menekankan persoalan untuk menguji hipotesis Friedman (1983;1984) yang menyatakan bahawa kemeruapan penawaran wang yang mempengaruhi halaju wang. Terdapat dua saluran bagaimana penawaran wang mempengaruhi halaju wang. Pertama, melibatkan kelakuan pendapatan benar dan kedua melalui kelakuan permintaan wang. Bukti empirikal untuk menguji faktor-faktor yang mempengaruhi halaju wang telah banyak dijalankan di negara maju dengan menggunakan pelbagai kaedah ekonometrik. Misalnya Hall dan Noble (1987) telah menggunakan ujian penyebab Granger (Granger-causality) untuk menunjukkan pengaruh kemeruapan penawaran wang terhadap halaju wang. Keputusan kajian tersebut menunjukkan kejatuhan dalam halaju wang M1 berpunca daripada peningkatan kemeruapan pertumbuhan penawaran wang. Keputusan kajian ini menjelaskan hubungan songsang antara perubahan halaju wang dengan perubahan penawaran wang. Kajian Mehra (1989) juga memberikan kesimpulan yang sama iaitu kemeruapan penawaran wang sempit (narrow money) signifikan mempengaruhi halaju wang, sebaliknya pengaruh kemeruapan penawaran wang meluas (broad money) tidak signifikan mempengaruhi halaju wang. Hasil kajian juga mendapati halaju wang M1 telah mengalami penurunan akibat daripada peningkatan kemeruapan penawaran wang. Selain itu, kajian terkini oleh Serletis dan Shahmoradi

IJMS 17 (1), 149-170 (2010) 
(2005) juga telah menyokong hipotesis Friedman yang menunjukkan bahawa kemeruapan penawaran wang juga signifikan mempengaruhi halaju wang. Kajian tersebut menggunakan kaedah multivariat GARCH dan model VARMA. Dua kaedah ukuran halaju wang telah digunakan dalam kajian ini iaitu kaedah penjumlahan mudah (simple sum) dan kaedah wang divisia (divisia money).

Di Malaysia, kajian mengenai isu halaju wang masih belum dikaji secara meluas dalam kalangan penyelidik tempatan. Sehingga kini, hanya terdapat dua kajian yang mengaitkan isu halaju wang di Malaysia. Misalnya, Setapa (1991) menyatakan bahawa pertimbangan terhadap halaju wang perlulah diberikan perhatian dalam menentukan ketidakstabilan gelagat penawaran wang di Malaysia. Ini disebabkan sebelum 1984, wang sempit (narrow money) telah digunakan sebagai pemboleh ubah sasaran. Walau bagaimanapun, akibat daripada perubahan dan kemajuan yang mendadak dalam inovasi dan deregulasi dalam sistem kewangan, BNM telah mengubah untuk mensasarkan agregat kewangan yang lebih meluas iaitu M3 untuk mengawal tekanan inflasi. Selain itu, kajian Azali (1996) cuba melihat hubungan arah sebab-menyebab antara halaju wang dengan komponen pertumbuhan wang yang dijangka (anticipated money) dan wang yang tidak dijangka (unanticipated money). Kajian tersebut menggunakan model VAR dan mendapati bahawa pertumbuhan penawaran wang yang dijangka dan tidak dijangka serta variabiliti pemboleh ubah penawaran tersebut signifikan mempengaruhi pertumbuhan halaju wang di Malaysia.

Walau bagaimanapun, kajian terdahulu di Malaysia tidak melihat beberapa aspek dengan lebih meluas. Pertama, tidak membentuk model halaju wang di Malaysia. Teori halaju wang menjelaskan bahawa terdapat beberapa faktor utama yang mempengaruhi halaju wang iaitu, pendapatan negara, kadar bunga deposit, kadar bunga bon, inovasi kewangan dan perubahan institusi. Pengaruh faktor-faktor tersebut terhadap halaju wang tidak dijelaskan oleh kajian terdahulu. Beberapa kajian empirikal yang lepas di negara maju seperti kajian Lucas (1988) dan McGrattan (1998) menunjukkan bahawa kadar bunga memainkan peranan penting dalam mempengaruhi - halaju wang. Kedua, sama ada halaju wang di Malaysia mengalami kemeruapan ataupun tidak merupakan persoalan empirikal yang menarik kerana ianya memberikan implikasi penting kepada perlaksanaan dasar kewangan negara. Ini kerana, jika halaju wang mengalami kemeruapan yang berkelangsungan (persistence), maka kawalan terhadap agregat kewangan perlulah dilakukan untuk mengelakkan kadar inflasi yang tinggi dalam jangka panjang. Ketiga, persoalan sama ada wujud hubungan jangka panjang antara halaju wang dengan pemboleh ubah bebas juga perlu diselidiki untuk mengesahkan lagi keberkesanan strategi dasar kewangan negara. Maka, akibat daripada beberapa kekangan kajian mengenai halaju

154 IJMS 17 (1), 149-170 (2010) 
wang di Malaysia, ianya telah memberikan motivasi kajian ini untuk menerokai isu halaju wang tersebut dengan lebih mendalam.

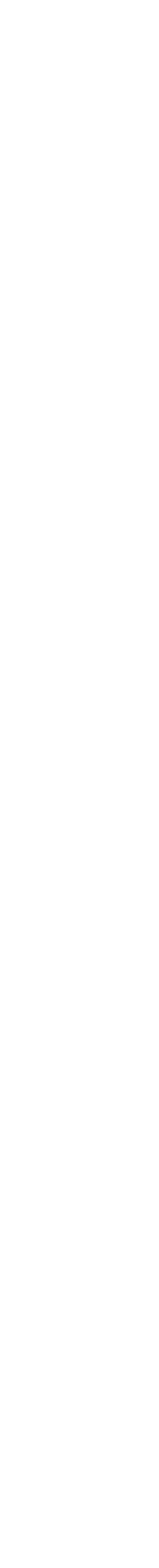

\section{Metodologi Kajian}

Bahagian ini membincangkan kerangka model yang digunakan untuk menganalisis kemeruapan halaju wang di samping menganggar fungsi halaju wang di Malaysia. Data yang digunakan adalah data suku tahunan yang bermula dari suku pertama tahun 1980 hingga suku ketiga tahun 2005 yang dikumpul dari Buletin Perangkaan Bulanan terbitan Bank Negara Malaysia. Hanya pemboleh ubah pendapatan negara $(Y)$ sahaja yang telah diubah bentuk kepada log semulajadi, manakala pemboleh ubah lain kekal dalam bentuk linear.

Dalam menganalisis hubungan yang wujud antara pemboleh ubah pemboleh ubah tersebut, beberapa ujian ekonometrik siri masa perlu dijalankan supaya penganggaran yang dibuat tidak menyalahi hukum ekonometrik. Pertama, ujian punca unit dilakukan bagi melihat tahap kepegunan pemboleh ubah siri masa sama ada pegun dalam bentuk paras atau pun pegun dalam bentuk pembezaan. Kedua, ujian kointegrasi pula dijalankan bagi melihat kemungkinan wujud hubungan jangka panjang antara pemboleh ubah kadar bunga deposit, kadar bunga bon dan pendapatan negara dengan pemboleh ubah halaju wang. Jika hubungan jangka panjang wujud, maka ujian model vektor pembetulan ralat (VECM) pula perlu dilakukan. Ujian ini berupaya menerangkan pelarasan jangka pendek akibat daripada kejutan ke atas keseimbangan jangka panjang. Ia juga mampu melihat arah hubungan sebab-menyebab antara pemboleh ubah bebas dengan pemboleh ubah bersandar sama ada bersifat jangka panjang atau jangka pendek.

\section{Ujian Punca Unit}

Ujian punca unit dilakukan untuk melihat tahap kepegunan setiap pemboleh ubah. Sesuatu pemboleh ubah dikatakan pegun jika min dan variannya adalah konstan melalui masa. Ia boleh menjadi pegun sama ada dalam peringkat paras (level), atau pun pembezaan (difference). Setiap pemboleh ubah dalam persamaan regresi perlu pegun pada tahap yang sama, iaitu sama ada semua pemboleh ubah pegun dalam bentuk paras atau semua pemboleh ubah pegun dalam bentuk pembezaan, misalnya pembezaan pertama. Syarat ini perlu dipenuhi agar anggaran yang didapati sah digunakan. Jika tidak, anggaran regresi palsu akan wujud, iaitu keputusan anggaran didapati sangat baik tetapi hubungan sebenarnya tidak wujud. Granger dan Newbold (1974) menyatakan bahawa keadaan ini boleh dikenal pasti apabila nilai $\mathrm{R}^{2}$ lebih besar daripada nilai statistik $\mathrm{DW}^{1}$.

IJMS 17 (1), 149-170 (2010) 
Dalam kajian ini, ujian punca unit kaedah Dickey-Fuller (1981) atau DF dan Imbuhan (Augmented) Dickey-Fuller (ADF) diaplikasikan².

\section{Ujian Kointegrasi Johansen}

Secara khususnya, fungsi model persamaan jangka panjang bagi halaju wang di Malaysia yang dianggarkan adalah berbentuk seperti berikut;

$$
V^{e}=v_{0}-v_{1} R_{d}+v_{2} I \pm v_{3} Y+\varepsilon_{t}
$$

Persamaan (6) merupakan model multivariat. Justeru, ujian kointegrasi Johansen (1988) dan Johansen dan Juselius (1990) adalah lebih sesuai digunakan. Ujian kointegrasi Johansen pada dasarnya melihat hubungan antara pangkat (rank) sesuatu matrik dengan punca cirinya (characteristic roots). Katakan terdapat satu model vektor autoregresi (VAR) pada tahap $p$ seperti berikut;

$$
y_{t}=A_{1} y_{t-1}+\ldots+A_{p} y_{t-p}+B x_{t}+\varepsilon_{t},
$$

yang mana $y_{t}$ adalah vektor pemboleh ubah yang tidak pegun $I(1), x_{t}$ pula adalah vektor $d$ pemboleh ubah penentu dan akhirnya $\varepsilon_{\mathrm{t}}$ adalah satu inovasi vektor. Dengan menyusun semula persamaan (7) di atas, persamaan (8) terbentuk seperti berikut;

$$
\Delta y_{t}=\Pi y_{t-1}+\sum_{i=1}^{p-1} \Gamma_{i} \Delta y_{t-i}+B x_{t}+\varepsilon_{t}
$$

yang mana

$$
\Pi=\sum_{i=1}^{p} A_{i}-I, \Gamma_{i}=-\sum_{j=i+1}^{p} A_{j}
$$

Teori Granger menyatakan jika koefisien matrik $\Pi$ mempunyai pangkat terturun $\mathrm{r}<\mathrm{k}$, maka akan wujud satu matrik $\mathrm{k} \times \mathrm{r}$ untuk $\alpha$ dan $\beta$ setiap satu mempunyai pangkat $\mathrm{r}$ iaitu $\Pi=\alpha \beta^{\prime}$ dan $\beta^{\prime} y_{t}$ adalah tidak pegun. $\mathrm{r}$ ialah bilangan hubungan kointegrasi atau pangkat kointegrasi, manakala setiap jalur $\beta$ pula adalah vektor kointegrasi. Elemen $\alpha$ dikenali sebagai parameter pelarasan dalam model vektor pembetulan ralat.

Kaedah Johansen menganggarkan matriks $\Pi$ dalam bentuk terturun dan seterusnya menguji sama ada kekangan yang terbentuk dalam bentuk terturun $\Pi$ boleh ditolak atau sebaliknya. Nilai kritikal yang digunakan dalam kajian ini adalah berdasarkan nilai kritikal yang dilaporkan oleh Osterwald-Lenum (1992). Disebabkan kaedah Johansen amat sensitif dengan jumlah lat yang digunakan, maka kajian ini menggunakan kriteria 


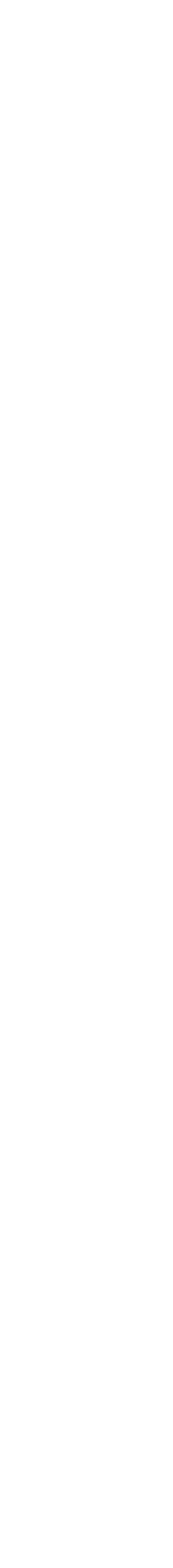

maklumat Akaike (1977) atau AIC untuk menentukan jumlah lat yang optimum sebelum penganggaran kaedah Johansen dilakukan.

\section{Model Vektor Pembetulan Ralat (VECM)}

Bagi melihat arah hubungan sebab-menyebab antara pemboleh ubahpemboleh ubah yang digunakan, ujian sebab menyebab Granger $(1969 ; 1988)$ digunakan. Namun begitu, jika pemboleh ubah-pemboleh ubah tersebut berkointegrasi pada darjah integrasi sama dengan satu atau I(1), maka sebutan pembetulan ralat tertangguh perlu dimasukkan ke dalam model sebelum ujian sebab-menyebab Granger boleh dilakukan. Engle dan Granger (1987) dan Toda dan Phillips (1993) berpendapat, kegagalan mengambil kira sebutan pembetulan ralat ini akan menyebabkan ujian yang dilakukan menghasilkan kesalahan spesifikasi model (model misspecification). Oleh yang demikian, ujian sebab-menyebab Granger perlulah dianggar dalam versi model vektor pembetulan ralat (VECM) seperti berikut;

$$
\Delta V_{t}=\alpha_{10}+\lambda_{v} \hat{\varepsilon}_{t-1}+\sum_{i=1}^{n} \delta_{1 i} \Delta V_{t-i}+\sum_{i=1}^{n} \phi_{1 i} \Delta I_{t-i}+\sum_{i=1}^{n} \gamma_{1 i} \Delta R_{t-i}+\sum_{i=1}^{n} \eta_{1} \Delta Y_{t-i}+v_{1 t}
$$

Model dalam persamaan (9) merupakan model multivariat. Simbol $\Delta$ adalah pembezaan pertama. $\Delta V=$ pembezaan pertama pemboleh ubah halaju wang (V1, V2 dan V3), $\Delta I=$ pembezaan pertama kadar bunga bon kerajaan (bil perbendaharaan), $\Delta R=$ pembezaan pertama kadar bunga deposit, dan $\Delta Y=$ pembezaan pertama Keluaran Dalam Negara Kasar. Sebutan $\hat{\varepsilon}_{\mathrm{t}-1}$ ialah sebutan pembetulan ralat tertangguh iaitu ralat daripada persamaan vektor kointegrasi yang dihasilkan oleh ujian kointegrasi Johansen. Sekiranya ujian kointegrasi yang telah diterangkan di atas membuktikan bahawa tiada kointegrasi, sebutan pembetulan ralat tertangguh ini akan disingkirkan daripada persamaan VECM di atas.

Kelebihan analisis dengan menggunakan model VECM adalah dapat mengasingkan kesan jangka pendek dan jangka panjang sesuatu pemboleh ubah penerang terhadap pemboleh ubah bersandar. Kesan jangka panjang pemboleh ubah penerang terhadap pemboleh ubah bersandar dapat ditentukan melalui sebutan pembetulan ralat tertangguh. Koefisien $\lambda_{V}$ akan mengukur kesan jangka panjang pemboleh ubah kadar bunga bon kerajaan (I), kadar bunga deposit (R) dan pendapatan negara (Y) terhadap halaju wang (V). Kesan jangka panjang ini wujud jika statistik ujian $t$ bagi koefisien berkenaan adalah signifikan pada aras keertian tertentu.

Hubungan sebab-menyebab Granger jangka pendek pula akan dapat dilihat melalui ujian wald (statistik $F$ ) terhadap sekumpulan koefisien yang berkenaan. Misalnya, daripada persamaan (9), penolakan $H_{0}: \phi_{1}=\phi_{2}=\ldots=\phi_{1 n}=0$ bermaksud kadar bunga bon kerajaan (I) 
adalah penyebab Granger jangka pendek kepada halaju wang (V), manakala penolakan $H_{0}: \gamma_{11}=\gamma_{12} \ldots \gamma_{1 n}=0$ pula membawa maksud kadar bunga deposit (R) adalah penyebab Granger jangka pendek kepada halaju wang (V). Manakala, penolakan hipotesis $H_{0}: \eta_{11}=\eta_{12} \ldots \eta_{1 \mathrm{n}}=0$ pula membawa maksud pendapatan negara $(\mathrm{Y})$ adalah penyebab Granger jangka pendek kepada halaju wang $(\mathrm{V})$. Jika tiada hubungan jangka panjang yang wujud antara pemboleh ubah, maka ujian penyebab Granger akan dilakukan untuk melihat hubungan jangka pendek yang mungkin terbentuk. Ujian ini serupa dengan ujian VECM dalam persamaan (9), melainkan faktor ralat - $\left(\varepsilon_{t-1}\right)$ kini diabaikan. Ia hanya dapat melihat hubungan jangka pendek yang wujud antara pemboleh ubah-pemboleh ubah yang dikaji.

\section{Ujian Kemeruapan (volatility) Halaju Wang}

Walau bagaimanapun, sebelum menguji hubungan jangka panjang dan arah hubungan sebab-menyebab, terlebih dahulu diuji sama ada halaju wang V1, V2 dan V3 meruap (volatile) ataupun tidak. Kajian ini menggunakan kaedah ARCH dan GARCH dalam kalangan pemboleh ubah tersebut. Secara amnya, model ARCH dan GARCH bagi model univariat dinyatakan seperti berikut;

$$
\sigma_{t}^{2}=\alpha_{0}+\alpha_{1} \mu_{t-1}^{2}+\alpha_{2} \sigma_{t-1}^{2}
$$

Persamaan (10) menjelaskan model mudah GARCH $(1,1)$ yang menyatakan bahawa varians bersyarat (conditional variance) bagi residual $(\mu)$ pada masa

- $t$ bukan sahaja bergantung kepada pemboleh ubah kuasadua ralat piawai pada tempoh lepas [ARCH (1)] tetapi juga bergantung kepada varians bersyarat dalam tempoh lepas. Model tersebut boleh juga dinyatakan dalam bentuk GARCH $(p, q)$ yang mana pialah lat ralat piawai yang dikuasaduakan dan $\mathrm{q}$ ialah lat varians bersyarat. Pemilihan lat optimum dalam model GARCH ditentukan dengan menggunakan kriteria maklumat Akaike (AIC) yang paling minimum. Jika koefisien $\alpha_{1}$ signifikan, maka ada kesan $\mathrm{ARCH}$ yang menjelaskan wujudnya kemeruapan dalam pemboleh ubah siri masa - tersebut. Begitulah sebaliknya, jika koefisien $\alpha_{2}$ signifikan maka ada kesan GARCH. Jika koefisien $\alpha_{1}+\alpha_{2}$ menghampiri 1, maka kemeruapan adalah mempunyai ciri kelangsungan (persistence).

\section{Keputusan Kajian}

\section{Analisis Statistik Deskriptif}

Rajah 1 menunjukkan arah aliran halaju wang yang semakin menurun mengikut masa, yang mana menjelaskan bahawa kadar perubahan 


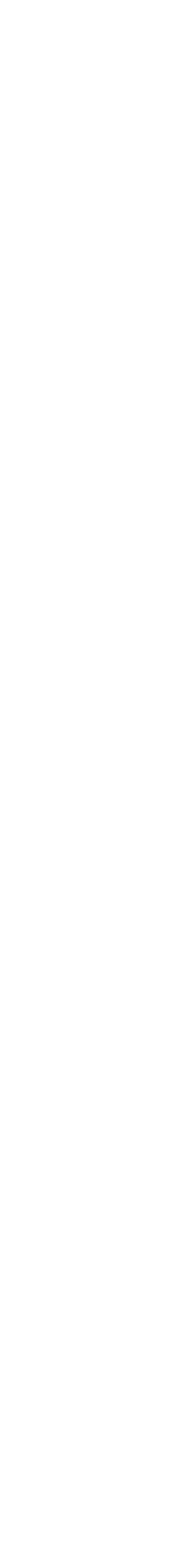

penawaran wang adalah lebih cepat daripada kadar perubahan pendapatan negara. Walau bagaimanapun, halaju wang sempit (V1) sentiasa melebihi halaju wang meluas (V2 dan V3) dalam tempoh kajian. Ini disebabkan halaju wang V1 mempunyai kecairan yang lebih tinggi berbanding dengan V2 dan V3. Sifat halaju wang V1 yang lebih cair ini menjelaskan bahawa wang M1 yang dipegang adalah untuk tujuan urus niaga, berbanding dengan wang M2 dan M3 yang dipegang untuk tujuan kekayaan. Selain itu, juga didapati kadar kejatuhan halaju wang V1 adalah lebih cepat berbanding dengan halaju wang V2 dan V3. Jika diperhatikan sebelum pertengahan tahun 1995, variabiliti halaju wang adalah lebih tinggi berbanding dengan selepas regim sasaran kadar bunga yang mula dilaksanakan oleh BNM mulai pertengahan tahun 1995 hingga kini.

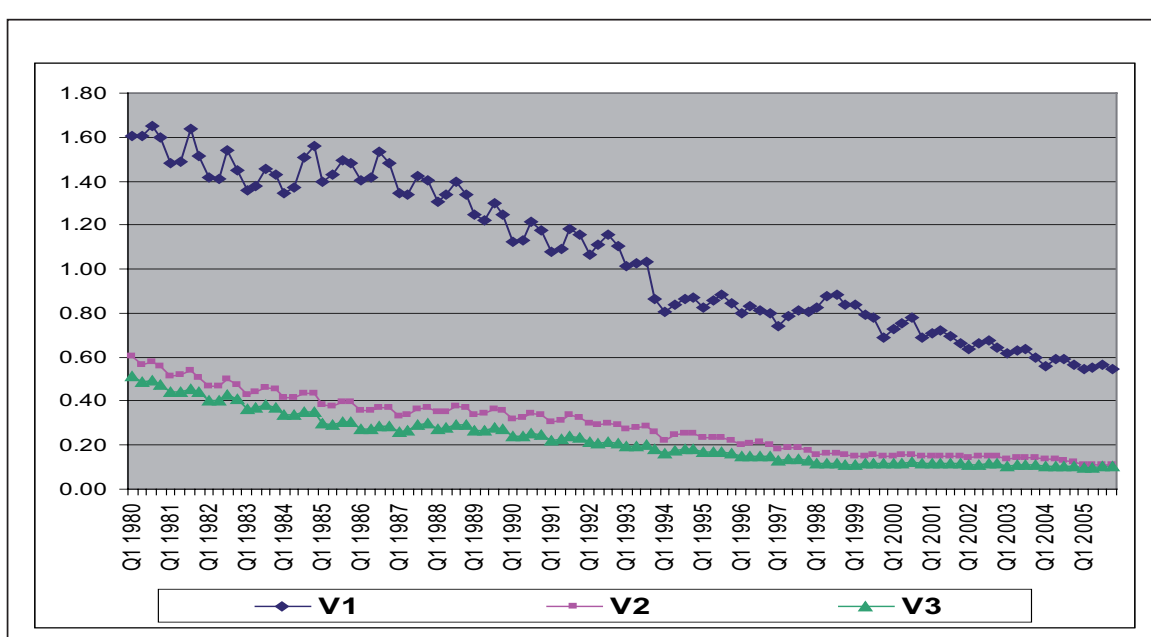

Rajah 1. Arah aliran halaju wang V1, V2 dan V3 dari tahun 1980:1 hingga 2005:4.

Jadual 1 pula menunjukkan nilai min, sisihan piawai dan koefisien variasi terhadap kadar pertumbuhan halaju wang V1,V2 dan V3 untuk menguji ciri kemeruapannya. Oleh kerana nilai min berbeza dengan sisihan piawai, maka sisihan piawai tidak sesuai digunakan untuk membandingkan kemeruapan halaju wang tersebut. Justeru, untuk menentukan tahap kemeruapan dalam kalangan halaju wang, maka ukuran koefisien variasi (nisbah antara sisihan piawai dengan nilai min) lebih tepat digunakan. Koefisien variasi tertinggi dicatatkan oleh V1 dengan nilai koefisien -5.9446, manakala V2 dan V3 masing-masing mempunyai koefisien variasi -3.3444 dan -3.4844. Ini bermakna kadar pertumbuhan halaju wang V1 adalah lebih meruap berbanding dengan V2 dan V3. Walau bagaimanapun, kaedah tersebut

IJMS 17 (1), 149-170 (2010) 
tidak dapat melihat tempoh kelangsungan (persistency) kemeruapan dalam kalangan halaju wang V1, V2 dan V3. Justeru, kaedah ARCH dan GARCH telah digunakan dalam kajian ini untuk melihat tempoh kelangsungan kemeruapan halaju wang tersebut. Keputusan ujian ARCH dan GARCH ditunjukkan dalam Rajah 2(a)-Rajah 2(c) dan Jadual 2.

\section{Jadual 1}

Min, Sisihan Piawai dan Koefisien Variasi bagi Kadar Pertumbuhan Semua Halaju - Wang

\begin{tabular}{lccc}
\hline & V1 & V2 & V3 \\
\hline Min & -0.8953 & -1.5090 & -1.4299 \\
Sisihan Piawai & 5.3222 & 5.0468 & 4.9824 \\
Koefisien Variasi & -5.9446 & -3.3444 & -3.4844 \\
\hline
\end{tabular}

\section{Keputusan Ujian ARCH dan GARCH}

Rajah 2(a)-Rajah 2(c) menunjukkan plot varians bersyarat (conditional variance) terhadap halaju wang V1, V2 dan V3 daripada model GARCH. Bagi halaju wang V1, dengan menggunakan model GARCH $(1,1)$ jelas menunjukkan terdapat perbezaan arah aliran yang ketara sebelum dan selepas regim kadar bunga pada pertengahan tahun 1995. Dalam hubungan ini dapat dilihat bahawa arah aliran yang menurun sebelum regim tetapi arah aliran meningkat setelah perlaksanaan regim kadar bunga.
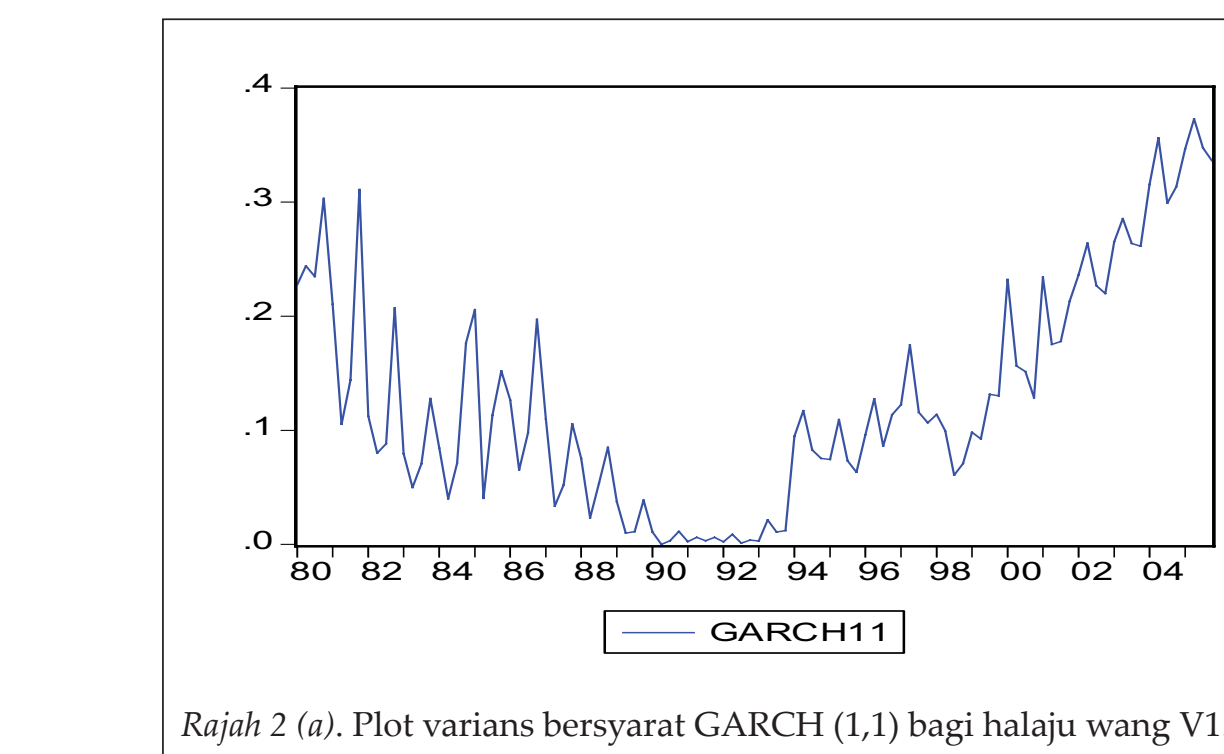

Rajah 2 (a). Plot varians bersyarat GARCH $(1,1)$ bagi halaju wang V1. 
Rajah 2(b) pula menunjukkan plot varians bersyarat bagi halaju wang V2 daripada penganggaran $\operatorname{GARCH}(1,2)$. Ia menjelaskan bahawa arah aliran halaju wang yang berbeza antara sebelum dan selepas perlaksanaan regim kadar bunga. Pada awal 1980-an, plot varians bersyarat menunjukkan arah aliran menurun dan meruap sehingga ia menghampiri sifar dari tahun 1986 hingga 1994. Bagaimanapun, selepas bermulanya regim kadar bunga, plot varians bersyarat menunjukkan arah aliran yang meningkat sepanjang tahun.

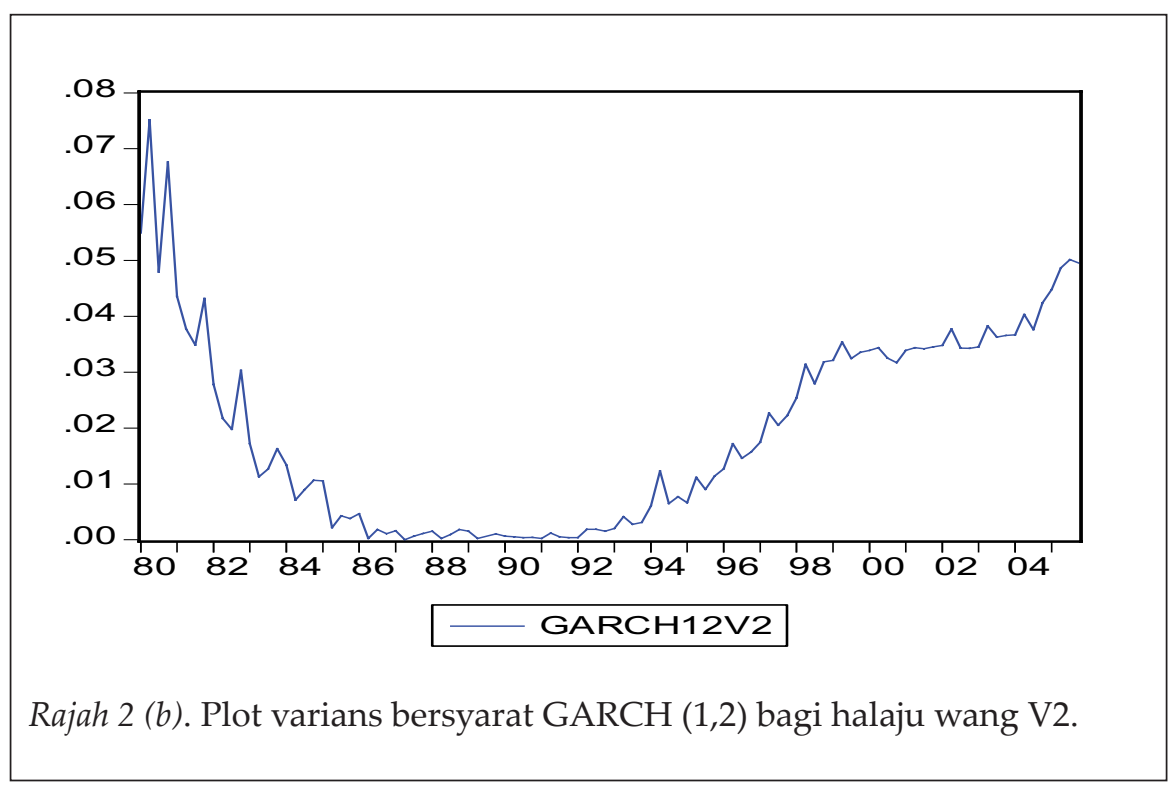

Rajah 2(c) pula menjelaskan plot varians bersyarat bagi penganggaran GARCH $(1,1)$, ke atas halaju wang V3 yang mana menampakkan perbezaan yang ketara berbanding dengan V1 dan V2. Pada awal 1980 hingga 1985, varians bersyarat turun mendadak dan meruap. Tetapi selepas itu, plot varians bersyarat menjadi stabil dan menghampiri sifar serta tidak meruap sepanjang tempoh sehingga tahun 2005.

Walau bagaimanapun, keputusan plot varians bersyarat pada Rajah 2(a)Rajah 2(c) tidak dapat menjelaskan sama ada kemeruapan halaju wang V1, V2 dan V3 mempunyai kelangsungan ataupun tidak dalam jangka panjang. Justeru, kaedah penganggaran model GARCH diperlukan untuk menjelaskan persoalan tersebut. Keputusan penganggaran model GARCH ditunjukkan pada Jadual 2.

IJMS 17 (1), 149-170 (2010) 161 


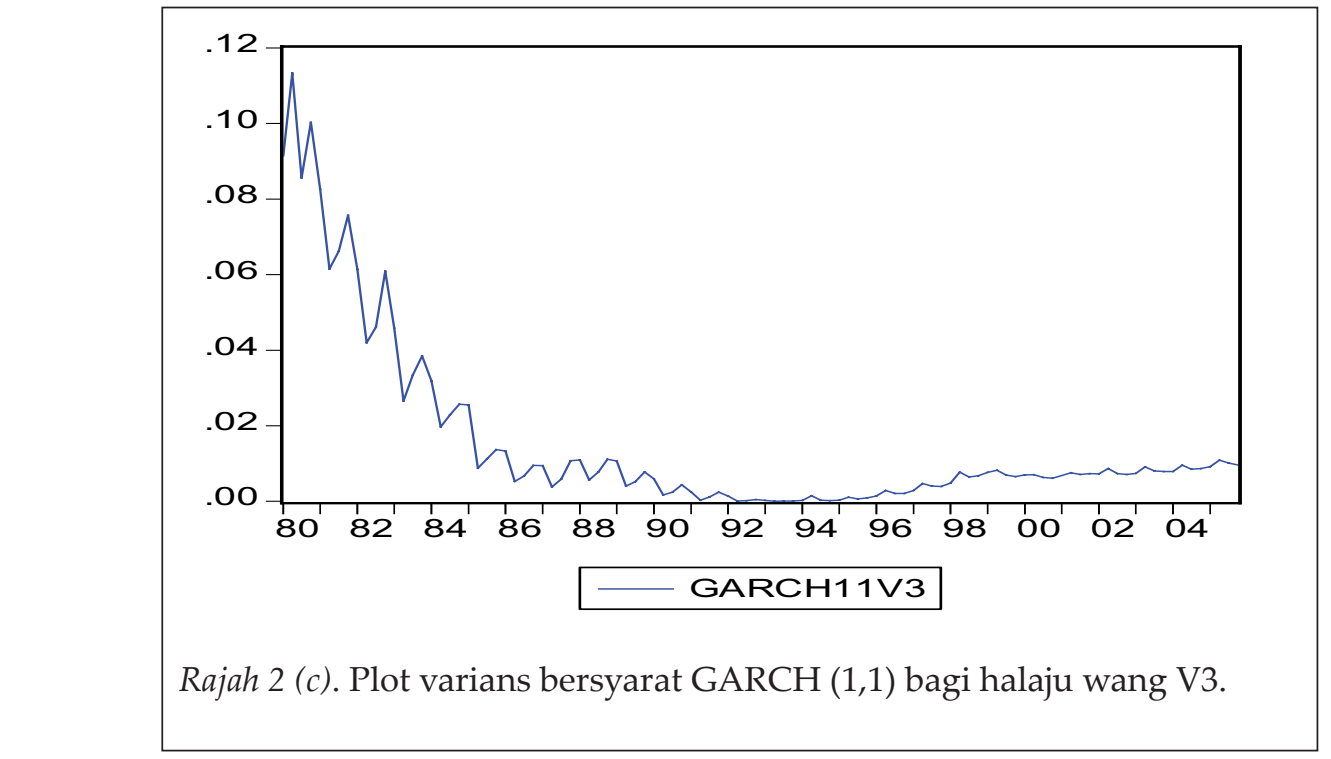

Daripada Jadual 2, tempoh kelangsungan (persistency) kemeruapan dalam kalangan halaju wang V1, V2 dan V3 boleh dilihat dengan menjumlahkan nilai koefisien persamaan varians $(\alpha+\beta)$. Jika hasil penjumlahan $(\alpha+\beta)$ menghampiri satu, maka ia menjelaskan halaju wang mempunyai kelangsungan kemeruapan dalam jangka panjang. Walau bagaimanapun, pemilihan nilai lat yang optimum dalam model GARCH perlu ditentukan - terlebih dahulu. Untuk itu, kajian ini menggunakan kaedah kriteria maklumat Akaike (AIC) yang paling minimum sebagai mewakili nilai lat yang paling optimum dalam model GARCH. Maka, model GARCH $(1,1)$ digunakan dalam halaju wang V1, GARCH $(1,2)$ untuk halaju wang V2 dan GARCH $(1,1)$ untuk halaju wang V3. Berdasarkan hasil kajian, didapati jumlah koefisien GARCH $(1,1)$ bagi V1 ialah 1.07 iaitu menghampiri satu yang bererti kemeruapan V1 mempunyai ciri kelangsungan (persistence) dalam jangka panjang. Manakala, nilai koefisien GARCH $(1,2)$ bagi V2 ialah - 0.9995 yang juga menghampiri nilai satu iaitu juga memberikan kesimpulan yang serupa dengan V1. Sebaliknya, koefisien GARCH $(1,1)$ bagi halaju wang V3 berjumlah 1.1071 yang menunjukkan tidak menghampiri nilai 1. Ini menjelaskan bahawa kemeruapan halaju wang V3 tidak mempunyai ciri kelangsungan dalam jangka panjang. Rumusannya, didapati halaju wang V1 dan V2 adalah lebih meruap berbanding dengan halaju wang M3. Ini menjelaskan bahawa, pihak BNM seharusnya membuat pemantauan pertumbuhan halaju wang V1 dan V2 secara bijak kerana mempunyai kemeruapan yang berkelangsungan. 


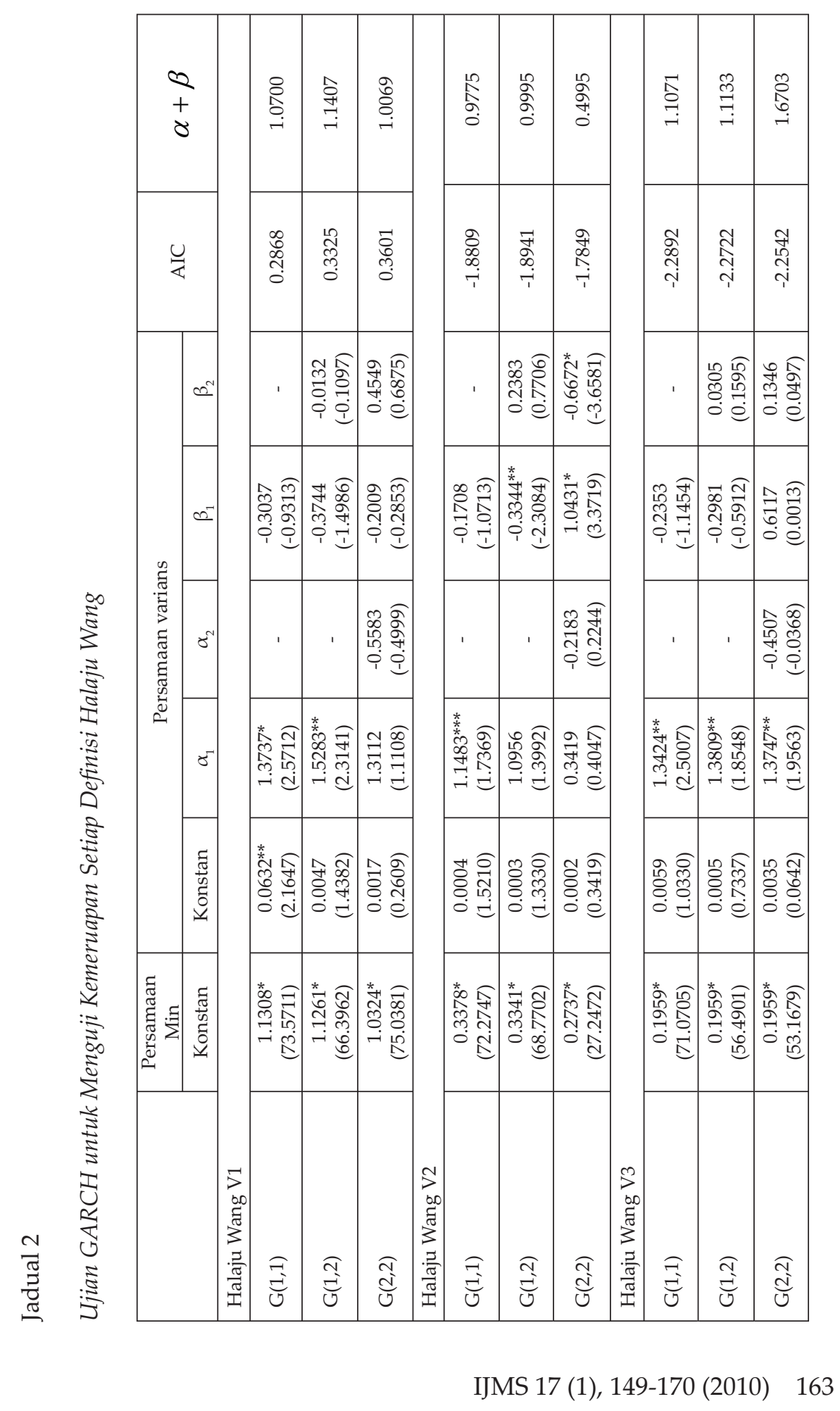




\section{Keputusan Ujian Punca Unit}

Setelah menentukan tahap kemeruapan dalam kalangan pemboleh ubah halaju wang, maka analisis kajian diteruskan dengan membincangkan model halaju wang di Malaysia. Justeru, sebelum membentangkan keputusan model halaju wang di Malaysia, ujian punca unit dibincangkan terlebih dahulu untuk menentukan darjah kepegunan sesuatu pemboleh ubah siri masa. Keputusan ujian punca unit kaedah ADF ditunjukkan pada Jadual 3. Bilangan lat ditentukan dengan kriteria maklumat Akaike (AIC) yang - diperkenalkan oleh Akaike (1977). Berdasarkan Jadual 3, didapati semua pemboleh ubah siri masa sama ada menggunakan regresi konstan tanpa tren atau dengan tren adalah tidak pegun pada tahap paras. Maka, siri masa perlulah diuji kepegunan pada tahap pembezaan pertama. Berdasarkan hasil kajian, didapati semua pemboleh ubah siri masa tersebut mencapai kepegunan pada tahap pembezaan pertama atau I(1). Ini bermakna semua pemboleh ubah tersebut mempunyai tren stokastik secara bersama mengikut masa.

Jadual 3

Ujian Kepegunan menggunakan Ujian Augmented Dickey Fuller (ADF)

\begin{tabular}{ccc}
\hline & $\tau_{\mu}$ & $\tau_{\tau}$ \\
\hline A. Paras I(0) & $-0.8706(6)$ & $-2.8592(4)$ \\
& $-1.6224(4)$ & $-1.5923(6)$ \\
V2 & $-2.7061(5)$ & $-2.0488(5)$ \\
V3 & $-1.7815(1)$ & $-2.0960(1)$ \\
I & $-2.2941(1)$ & $-3.3472(1)$ \\
$R_{d}$ & $-0.6989(1)$ & $-2.6997(1)$ \\
$R_{s}$ & $-0.5182(5)$ & $-1.7094(5)$ \\
Y & & \\
B. Pembezaan Pertama I(1) & $-5.0766^{*}(9)$ & $-5.0725^{*}(6)$ \\
V1 & $-4.8130^{*}(3)$ & $-4.8535^{*}(5)$ \\
V2 & $-3.8294^{*}(3)$ & $-4.1807^{*}(3)$ \\
V3 & $-9.6519^{*}(1)$ & $-9.6417^{*}(1)$ \\
I & $-5.8501^{*}(1)$ & $-5.8417^{*}(1)$ \\
$R_{d}$ & $-7.6173^{*}(1)$ & $-7.6357^{*}(1)$ \\
$R_{s}$ & $-4.1308^{*}(4)$ & $-4.1198^{*}(4)$ \\
Y & &
\end{tabular}

Nota. Ujian ADF; $\tau$ tanpa tren; $\tau$ dengan tren.

Tanda $\left({ }^{*}\right),\left({ }^{* *}\right)$ dan $\left(^{* * *}\right)$ masing-masing menunjukkan kepegunan pada aras keertian $1 \%, 5 \%$ dan $10 \%$. Kesemua pemboleh ubah adalah dalam bentuk log.

Nilai dalam kurungan merupakan nilai lat optimum yang ditentukan menggunakan kriteria AIC.

164 IJMS 17 (1), 149-170 (2010) 


\section{Keputusan Ujian Kointegrasi Johansen}

Oleh kerana, semua pemboleh ubah siri masa mencapai kepegunan pada tahap yang sama iaitu pembezaan pertama, maka ia membolehkan ujian kointegrasi dijalankan untuk melihat sama ada wujud ataupun tidak hubungan jangka panjang di kalangan pemboleh ubah siri masa tersebut. Untuk itu, kajian ini mengaplikasikan kaedah kointegrasi Johansen (1988) dan Johansen dan Juselius (1990). Gonzalo (1994) berpendapat bahawa ujian kointegrasi Johansen yang diperkenalkan oleh Johansen (1988) dan Johansen dan Juselius (1990), adalah kaedah yang terbaik berbanding dengan kaedah-kaedah yang lain. Keputusan yang diperolehi daripada kaedah Johansen ini mengambil kira sifat-sifat penting siri masa bagi datadata yang terlibat. Kaedah ini juga memberikan penganggaran untuk semua vektor kointegrasi yang wujud dalam sesuatu sistem siri masa dan statistik ujian yang sesuai. Di samping itu, kaedah Johansen juga membolehkan satu ujian hipotesis dapat dilakukan ke atas koefisien dalam vektor kointegrasi. Kaedah ini berdasarkan kepada penganggaran kebolehjadian maksimum (maximum likelihood estimation) yang menguji kewujudan vektor kointegrasi dalam kalangan siri masa.

Jadual 4 (a)

Ujian Kointegrasi Pemboleh Ubah Berbilang Johansen-Juselius menggunakan Ujian Trace

\begin{tabular}{crrrc}
\hline \multirow{2}{*}{ Ho : Tiada Kointegrasi } & \multicolumn{3}{c}{ Statistik Trace } & Nilai Kritikal \\
& V1 & V2 & V3 & 0.05 \\
\hline $\mathrm{r}=0$ & 45.726 & $79.972^{*}$ & $57.182^{*}$ & 47.856 \\
$\mathrm{r} \leq 1$ & 16.627 & $39.729^{*}$ & $30.882^{*}$ & 29.797 \\
$\mathrm{r} \leq 2$ & 7.803 & 11.865 & $16.099^{*}$ & 15.494 \\
$\mathrm{r} \leq 3$ & 0.851 & 3.919 & $7.221^{*}$ & 3.841 \\
\hline
\end{tabular}

${ }^{*}(*)$ Ujian Trace menunjukkan signifikan pada aras keertian 5\% (1\%).

Jadual 4 (b)

Ujian Kointegrasi Pemboleh Ubah Berbilang Johansen-Juselius menggunakan Ujian Maksimum Eigen

\begin{tabular}{ccccc}
\hline \multirow{2}{*}{ Ho: Tiada Kointegrasi } & \multicolumn{3}{c}{ Statistik Maks-Eigen } & Nilai Kritikal \\
& V1 & V2 & V3 & 0.05 \\
\hline $\mathrm{r}=0$ & $29.098^{*}$ & $40.243^{*}$ & $26.299^{*}$ & 27.584 \\
$\mathrm{r} \leq 1$ & 8.823 & $27.863^{*}$ & $14.782^{*}$ & 21.131 \\
$\mathrm{r} \leq 2$ & 6.952 & 7.946 & $8.878^{*}$ & 14.264 \\
$\mathrm{r} \leq 3$ & 0.851 & 3.919 & $7.221^{*}$ & 3.841 \\
\hline
\end{tabular}

${ }^{*}(* *)$ Ujian Maksimum Eigen menunjukkan signifikan pada aras keertian 5\% (1\%).

IJMS 17 (1), 149-170 (2010) 165 
Jadual 4(a)-4(b) menunjukkan keputusan ujian kointegrasi Johansen yang telah dijalankan dengan menggunakan dua jenis statistik ujian iaitu ujian trace dan ujian maksimum Eigen. Berdasarkan hasil kajian, didapati keduadua ujian statistik memberikan keputusan yang konsisten, kecuali bagi V1. Misalnya, bagi halaju wang V2 dengan menggunakan ujian trace dan ujian maksimum Eigen, didapati kewujudan dua persamaan vektor yang berkointegrasi dalam model persamaan. Keputusan ini menjelaskan bahawa wujud hubungan jangka panjang dalam kalangan pemboleh ubah siri masa tersebut. Begitu juga dengan halaju wang V3, sama ada menggunakan ujian trace atau ujian maksimum Eigen didapati kewujudan empat persamaan vektor yang berkointegrasi. Sebaliknya, bagi V1 jika menggunakan ujian trace didapati tidak wujud hubungan jangka panjang dalam kalangan pemboleh ubah siri masa tersebut, sebaliknya jika menggunakan kaedah ujian maksimum Eigen wujud satu persamaan vektor yang berkointegrasi. Justeru, untuk memudahkan analisis kajian ini menggunakan kaedah ujian maksimum Eigen untuk menentukan hubungan kointegrasi tersebut. Maka, berdasarkan ujian maksimum Eigen jelas menunjukkan semua halaju wang V1, V2 dan V3 mempunyai hubungan jangka panjang terhadap penentunya. Kewujudan kointegrasi bermakna terma pembetulan ralat (ECT) yang diperolehi daripada regresi kointegrasi mestilah diambil kira di dalam ujian sebab-menyebab untuk mengelakkan kesalahan spesifikasi model (Granger, 1988).

\section{Keputusan Ujian Model Vektor Pembetulan Ralat (VECM)}

Keputusan ujian kointegrasi Johansen dengan menggunakan kaedah ujian maksimum Eigen menunjukkan kewujudan hubunganjangka panjang antara halaju wang dengan penentunya. Walau bagaimanapun, ujian kointegrasi tersebut tidak dapat menjelaskan hubungan arah sebab-menyebab dalam kalangan pemboleh ubah siri masa. Justeru, ujian sebab-menyebab Granger perlu dilakukan. Oleh kerana wujudnya hubungan kointegrasi, maka ujian sebab-menyebab kaedah VECM perlulah mengambil kira sebutan pembetulan ralat tertangguh (ECT) dalam setiap persamaan model halaju wang. Keputusan ujian VECM diringkaskan pada Jadual 5. Didapati terma pembetulan ralat (ECT) tidak signifikan bagi halaju wang V1, yang bermakna tidak terdapat pelarasan untuk menuju keseimbangan jangka panjang bagi set pemboleh ubah V1 dan penentu-penentunya. Bagaimanapun, terma ECT adalah signifikan bagi V2 dan V3 pada aras keertian 5\%. Ini bermakna, wujudnya pelarasan dalam jangka pendek untuk menuju keseimbangan dalam jangka panjang dalam model tersebut.

Selain itu, hubungan jangka pendek antara halaju wang dan penentunya diterangkan melalui ujian penyebab Granger. Didapati kadar bunga bon kerajaan (I) tidak signifikan menjadi penyebab Granger bagi semua halaju 


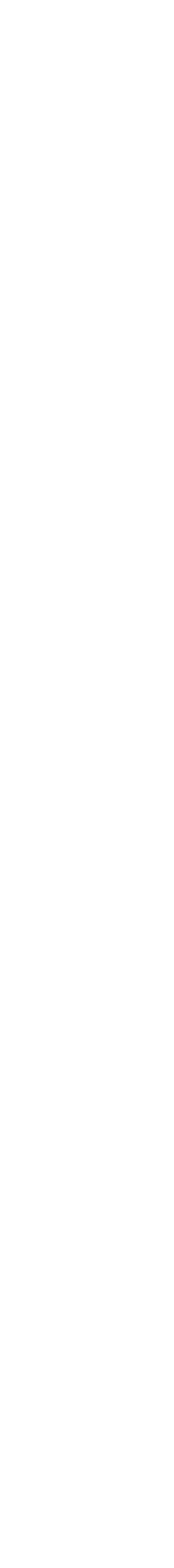

wang. Kadar bunga deposit atau kadar bunga simpanan (R) pula hanya signifikan menjadi penyebab Granger kepada halaju wang V3 dengan nilai koefisien yang tidak anjal tetapi selari dengan teori halaju wang. Bagaimanapun, pemboleh ubah pendapatan negara $(Y)$ signifikan menjadi penyebab Granger jangka pendek terhadap halaju wang V1 dan V3 pada aras keertian sekurang-kurangnya $5 \%$. Hubungan negatif antara perubahan pendapatan (Y) dengan halaju wang V1 dan V3 menjelaskan bahawa permintaan wang adalah sangat anjal terhadap perubahan pendapatan negara. Sebaliknya, hubungan sebab-menyebab jangka panjang hanya berlaku terhadap halaju wang V2 dan V3 sahaja. Ini dibuktikan melalui nilai $\wedge$

statistik-t bagi pemboleh ubah $\left(\varepsilon_{t-1}\right)$ yang signifikan pada aras keertian $1 \%$. Hal ini menjelaskan bahawa perubahan pemboleh ubah kadar bunga bon kerajaan (I), kadar bunga deposit (R) dan pendapatan negara (Y) signifikan mempengaruhi perubahan halaju wang V2 dan V3 dalam jangka panjang.

Jadual 5

Ujian Penyebab dalam Model VECM

\begin{tabular}{cccc}
\hline \multirow{2}{*}{ Pemboleh Ubah Bebas } & \multicolumn{3}{c}{ Pemboleh Ubah Bersandar } \\
\cline { 2 - 4 } & $\Delta$ V1 (Lat 3) & $\Delta$ V2 (Lat 3) & $\Delta$ V3 (Lat 5) \\
\hline \multirow{2}{*}{ ECT ${ }_{\mathrm{t}-1}$} & -0.0801 & $-0.1809^{*}$ & $-0.0027^{*}$ \\
& $(-0.8280)$ & $(-5.7187)$ & $(-4.7012)$ \\
$\Delta \mathrm{I}$ & 0.0047 & 0.0025 & -0.0039 \\
& $(0.4217)$ & $(1.4966)$ & $(-1.4871)$ \\
$\Delta \mathrm{R}$ & 0.0046 & -0.0011 & $-0.0202^{*}$ \\
& $(0.4708)$ & $(-0.5179)$ & $(-5.6327)$ \\
$\Delta \mathrm{Y}$ & $-0.9161^{*}$ & -0.0398 & $-0.1194^{* *}$ \\
& $(-9.1876)$ & $(-1.2387)$ & $(-2.6279)$ \\
\hline
\end{tabular}

Nilai dalam kurungan adalah statistik F.

Lat optimum ditentukan oleh kriteria Schwarz.

Tanda $\left.{ }^{* * *}\right)^{* * *}$ menunjukkan signifikan pada aras $1 \%(5 \%) 10 \%$.

Ujian F bagi keseluruhan lat dilakukan menggunakan Ujian Wald.

\section{Rumusan dan Implikasi}

Kajian ini bertujuan untuk menguji kemeruapan halaju wang di samping menganggar fungsi halaju wang di Malaysia dengan menggunakan kaedah ekonometrik terkini seperti model ARCH, GARCH, kaedah ujian kointegrasi Johansen dan model vektor pembetulan ralat (VECM). Berdasarkan hasil kajian didapati, halaju wang V1 dan V2 mempunyai kelangsungan kemeruapan dalam jangka panjang, sebaliknya halaju wang V3 tidak 
mempunyai ciri kelangsungan kemeruapan. Keputusan ujian kointegrasi Johansen pula menunjukkan kewujudan hubungan jangka panjang antara halaju wang V1, V2 dan V3 dengan pemboleh ubah penentunya yang terdiri daripada kadar bunga bon, kadar bunga deposit dan pendapatan negara. Keputusan ujian VECM pula menunjukkan bahawa, perubahan pendapatan negara signifikan mempengaruhi perubahan halaju wang V1 dan V3 dalam jangka pendek, sebaliknya perubahan kadar bunga deposit hanya signifikan mempengaruhi perubahan halaju wang V3 sahaja. Dalam jangka panjang, didapati semua pemboleh ubah bebas (kadar bunga bon kerajaan, kadar bunga deposit dan pendapatan negara) signifikan mempengaruhi perubahan halaju wang V2 dan V3.

Penemuan kajian ini memberikan implikasi penting kepada perlaksanaan dasar kewangan negara. Oleh kerana halaju wang yang sempit iaitu V1 dan V2 mempunyai kemeruapan yang berkelangsungan dalam jangka panjang berbanding dengan halaju wang V3 yang secara relatifnya lebih stabil, maka adalah lebih sesuai Bank Negara Malaysia (BNM) membuat kawalan terhadap agregat kewangan yang luas iaitu M3. Mengikut Cagan (1982), agregat kewangan yang mempunyai halaju yang stabil iaitu kurang mengalami kemeruapan merupakan agregat kewangan yang terbaik untuk digunakan sebagai sasaran pertengahan dasar kewangan. Justeru, berdasarkan kepada penemuan kajian jelas menunjukkan bahawa BNM seharusnya memilih agregat kewangan M3 sebagai sasaran dasar kewangan kerana mempunyai halaju yang lebih stabil. Maka, dalam hal ini BNM seharusnya memantau perkembangan halaju wang V3 dari masa ke semasa dengan menggunakan alat dasar kewangan yang bersesuaian.

Walau bagaimanapun, kajian ini tidak mengambil kira pengaruh perubahan institusi dan kesan inovasi kewangan terhadap halaju wang di Malaysia. Justeru, kajian pada masa hadapan perlulah mengambil kira peranan pemboleh ubah tersebut kerana faktor tersebut sangat penting dalam mempengaruhi gelagat permintaan wang dalam kalangan orang ramai, yang mana seterusnya akan mempengaruhi halaju wang.

\section{Nota Akhir}

1. DW ialah statistik Durbin-Watson untuk melihat kewujudan masalah autokorelasi.

2. Penerangan lanjut mengenai ujian punca unit Dickey-Fuller (DF) dan Augmented Dickey-Fuller (ADF) tidak dilakukan kerana kesemuanya telah dianggap sebagai ujian yang standard dalam analisis data siri masa. 


\section{Rujukan}

Akaike, H. (1977). On entropy maximasitation principle. In. P.R. Krishniah (Eds.), Application of Statistics. North-Holland, Amsterdam.

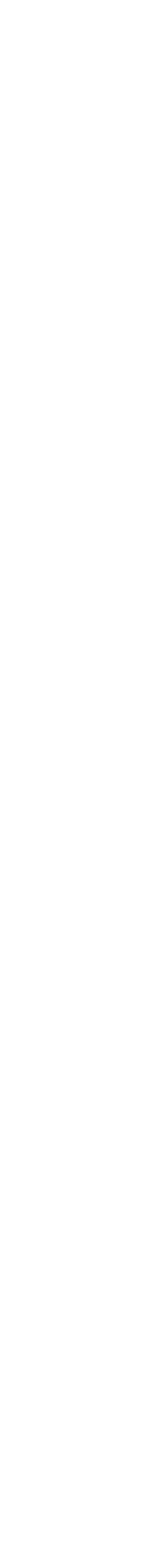

Azali, M. (1996). Velocity and the variability of anticipated and unanticipated money growth in Malaysia. Applied Economics Letters, 3, 697-700.

Bordo, M.D., \& Jonung, L. (1981). The long-run behaviour of the income velocity of money in five advanced countries: An institutional approach. Economic Inquiry, 19, 96-116.

Bordo, M.D., \& Jonung, L. (1987). The long-run behaviour of the velocity of circulation. Cambridge: Cambridge University Press.

Cagan, P. (1982). The choice among monetary aggregates as target and guides for monetary policy. Journal of Money, Credit and Banking, 14(4), 661-686.

Dickey, D.A., \& Fuller, W.A. (1981), Likelihood ratio statistics for autoregressive time series with a unit root. Econometrica, 49, 1057-1071.

Engle, R.F., \& Granger. C.W.J. (1987). Co-integration and error correction: Representation, estimation, and testing. Econometrica, 55, 251-276.

Fisher, I. (1930). The theory of interest. New York: MacMillan.

Friedman, M. (1983). Monetary variability: The United States and Japan. Journal of Money, Credit and Banking, 15, 339-343.

Friedman, M. (1984). Lesson from the 1979-1982 monetary policy experiment. American Economic Review, 74, 397-400.

Gonzalo, J. (1994). Five alternative methods of estimating long-run equilibrium relationships. Journal of Econometrics, 60, 203-233.

Granger, C.W.J. (1969). Investigating causal relations by econometrics models and cross-spectral methods. Econometrica, 55, 251-276.

Granger, C.W.J. (1988). Some recent development in a concept of causality. Journal of Econometrics, 39, 199-211.

Granger, C.W.J., \& Newbold, P. (1974). Spurious regressions in econometrics. Journal of Econometrics, 2, 111-120.

Hall, T.E., \& Noble, N.R. (1987). Velocity and the variability of money growth: Evidence from granger causality tests. Journal of Money, Credit and Banking, 19, 112-116.

Johansen, S., \& Juselius, K. (1990). Maximum likelihood estimation and inferences on cointegration with application to the demand for money. Oxford Bulletin of Economics and Statistics, 52, 169-210

Johansen, S. (1988). Statistical analysis of cointegration vectors. Journal of Economic Dynamic Control, 12, 231-254.

Lucas, Jr. R.E. (1988). Money demand in the United States: A quantitative review. In: Brunner, K., Meltzer, A.H (Eds.), Money, Cycles and

IJMS 17 (1), 149-170 (2010) 169 
Exchange Rates: Essays in honor of Allan H. Meltzer, Carnegie-Rochester Conference Series, 29. North-Holland, Amsterdam, 137-168.

McGrattan, E.R. (1998). Trends in velocity and policy expectations: A comment, Carnegie-Rochester Conference Series on Public Policy, 49, 305-316.

Mehra, Y.P. (1989). Velocity and the variability of money growth: Evidence from granger-causality tests. Journal of Money, Credit and Banking, 21(2), $262-266$.

Osterwald-Lenum, M. (1992). A note with quantiles of the asymptotic distributrion of the maximum likelihood cointegration rank test statistics. Oxford Buletin of Economics and Statistics, 54, 461-471.

Serletis, A., \& Shahmoradi, A. (2005). Velocity and the variability of money growth: Evidence from a VARMA, GARCH-M model. Discussion Paper 2005-18, Department of Economics, University of Calgary, Alberta, Canada.

Setapa, A. (1991). The conduct and the effectiveness of monetary policy in Malaysia. (Unpublished PhD Dissertation). University of Exeter.

Toda, H.Y., \& Phillips, P.C.B. (1993). Vectors auto regressions and causality. Econometrica, 13, 67-1393. 